Brit. J. Vener. Dis. (1963), 39, 18.

\title{
GENITAL STRAINS OF HUMAN PLEUROPNEUMONIA-LIKE ORGANISMS*
}

\author{
BY \\ D. K. FORD AND M. DUVERNET \\ Department of Medicine, University of British Columbia, Vancouver, Canada
}

Klieneberger-Nobel (1961) reviewed in detail the significance of large-colony pleuropneumonia-like organisms (PPLO) in the human genital tract. Unfortunately, at that time, the existence of T-strain PPLO, as described by Shepard (1956), was under dispute. Subsequently, however, Shephard's observation that T-strain PPLO could be isolated from the majority of patients with non-gonococcal urethritis was confirmed (Ford, Rasmussen, and Minken, 1962), the continuous propagation of $T$-strains was achieved (Ford, 1962), and their morphological definition as PPLO was demonstrated (Ford and MacDonald, 1963). In order to assess the significance of T-strains and large-colony PPLO in the human genital tract, a survey was made to determine, by cultural methods, the incidence of these organisms in different categories of individuals.

Patients with non-gonococcal urethritis were seen at the Vancouver Venereal Diseases Control Clinic, adjacent to the Vancouver General Hospital. For inclusion in the study the patients had to have a visible urethral discharge which failed to reveal gonococci by smear and culture. Cases were excluded if they had received broadspectrum antibiotics or if the discharge had been present longer than one month.

\section{Methods}

Patients were examined and specimens collected by the senior author or by two students associated with the project. After the insertion of a platinum loop 1 to 2 inches within the urethra, culture media were inoculated directly. Specimens were obtained from "control" males by the insertion of a specially-made small cotton-wool swab, moistened in broth, on a wire holder. A comparison of this swab method with the loop method in 29 cases of non-gonococcal urethritis showed no difference in isolation rate between the two techniques.

* Received for publication November 20, 1962.
Two types of male "controls" without urethritis were studied: one hundred newly committed inmates of the local gaol and one hundred Services' recruits-about half of whom were apprentices between the age of 16 and 20 .

Two types of female subject were investigated by vaginal swabbing: fifty private patients from four consulting gynaecologists practising near the hospital and 21 women inmates of the local gaol.

Specimens were inoculated directly on to agar media; alternatively the loop or swab was placed in $0.5 \mathrm{ml}$. broth from which drops were transferred on to varying media. Initially Shepard's agar (Shepard, 1956) was employed; subsequently Difco PPLO medium enriched with 10 per cent. horse serum and 10 per cent. of a 25 per cent. boiled, active yeast extract was found to be equally effective and used routinely (Ford, 1962). In addition, the medium of Klieneberger-Nobel (1959) was studied and compared with the other media. Incubation was done routinely at $36^{\circ} \mathrm{C}$. in 10 per cent. $\mathrm{CO}_{2}$ but comparisons were made with Fortner's anaerobic method, aerobic incubation, and incubation in 20 per cent. $\mathrm{CO}_{2}$ with 80 per cent. nitrogen. All cultures were studied with Dienes's method of staining by both low-power and oilimmersion microscopy. All specimens from patients with non-gonococcal urethritis were observed on media both free of penicillin and containing 1,000 units penicillin per $\mathrm{ml}$. Specimens from female patients and "control" males contained greater numbers of bacteria so that the nonpenicillin plates were usually overgrown by bacterial colonies.

\section{Results}

Table I (opposite) shows the isolation rates of T-strain and large-colony PPLO from the three categories of male subjects. T-strain colonies were seen in the cultures from 21,47 , and 79 per cent. of the recruits, goal inmates, and patients with nongonococcal urethritis respectively. Large-colony PPLO were seen in the cultures from 10, 37, and 27 per cent. of the same groups. Some individuals in each category harboured both types of organism; 
24 per cent. of recruits, 55 per cent. of gaol inmates, and 84 per cent. of patients with non-gonococcal urethritis yielded PPLO of either type from the genital tract. It is thus evident that both types of PPLO were commonly found in the urethra in the absence of urethritis. However, whereas the incidence of large-colony PPLO was higher in gaol inmates without urethritis than in patients with nongonococcal urethritis, the incidence of $\mathrm{T}$-strain PPLO was almost twice as high in the patients with non-gonococcal urethritis as in the asymptomatic gaol inmates.

TABLE I

INCIDENCE OF GENITAL PPLO IN MEN

\begin{tabular}{|c|c|c|c|c|c|c|c|}
\hline \multirow{2}{*}{\multicolumn{2}{|c|}{$\begin{array}{l}\text { Groups Examined } \\
\text { No. of Cases Studied. }\end{array}$}} & \multicolumn{2}{|c|}{$\begin{array}{l}\text { Services' } \\
\text { Recruits }\end{array}$} & \multicolumn{2}{|c|}{$\underset{\text { Inmates }}{\text { Gaol }}$} & \multicolumn{2}{|c|}{$\begin{array}{l}\text { Patients with } \\
\text { Non- } \\
\text { gonococcal } \\
\text { Urethritis }\end{array}$} \\
\hline & & \multicolumn{2}{|c|}{100} & \multicolumn{2}{|c|}{100} & \multicolumn{2}{|c|}{100} \\
\hline \multirow{4}{*}{$\begin{array}{l}\text { No. of } \\
\text { PPLO } \\
\text { Isola- } \\
\text { tions }\end{array}$} & ${ }^{\mathrm{T} \text {-strains }}$ Only & 14 & \multirow{3}{*}{$\begin{array}{r}21 \\
\cdot 10\end{array}$} & 18 & \multirow[b]{3}{*}{37} & 57 & \multirow{3}{*}{$\begin{array}{l}79 \\
27\end{array}$} \\
\hline & Both Strains & 7 & & 29 & & 22 & \\
\hline & $\begin{array}{l}\text { Large-Colony } \\
\text { Strains Only }\end{array}$ & 3 & & 8 & & 5 & \\
\hline & Total PPLO & \multicolumn{2}{|l|}{24} & \multicolumn{2}{|l|}{55} & \multicolumn{2}{|l|}{84} \\
\hline
\end{tabular}

Table II shows the cultural findings in the two groups of female subjects.

(1) Through the co-operation of four gynaecological specialists, a group of women attending their private consulting rooms for varied gynaecological complaints was investigated. Of fifty such private patients, T-strain PPLO were isolated from 22 and large-colony PPLO from six. Eight of the 25 patients, from whom one or both types of PPLO were isolated, had leucorrhoea at the time of the gynaecologists' examinations.

(2) 21 women inmates of the local gaol were investigated; the majority may be assumed to be prostitutes. Unfortunately it was impossible to assess the incidence of T-strain PPLO in this group

TABLE II

INCIDENCE OF PPLO IN WOMEN

\begin{tabular}{|c|c|c|c|c|c|}
\hline \multicolumn{2}{|c|}{ Groups Examined } & . & $\ldots$ & $\begin{array}{c}\text { Private } \\
\text { Gynaecology } \\
\text { Patients }\end{array}$ & $\underset{\text { Inmates }}{\text { Gaol }}$ \\
\hline \multicolumn{2}{|c|}{ No. of Cases Studied } & & $\ldots$ & 50 & 21 \\
\hline \multirow{4}{*}{$\begin{array}{c}\text { PPLO } \\
\text { Isolated } \\
\text { on } \\
\text { Culture }\end{array}$} & \multirow{2}{*}{ T. strains . . } & No. & . & 22 & \multirow{2}{*}{$\begin{array}{l}\text { Cultures } \\
\text { overgrown } \\
\text { by many } \\
\text { large-colony } \\
\text { PPLO }\end{array}$} \\
\hline & & \multicolumn{2}{|c|}{ Per cent. } & 44 & \\
\hline & \multirow{2}{*}{$\begin{array}{c}\text { Large-Colony } \\
\text { Strains } \quad .\end{array}$} & No. & . & 6 & 18 \\
\hline & & Per cer & & 12 & 86 \\
\hline
\end{tabular}

because the overwhelming majority of the culture plates were so overgrown with numerous largecolony PPLO that T-strain colonies could not be defined.

Table III shows a comparison of the efficiency of the two media employed for the cultural isolation of T-strain and large-colony PPLO. Both the enriched Difco medium and the medium of KlienebergerNobel grew both cultures with almost equal success. The Table suggests that the Klieneberger-Nobel medium was slightly more effective for the growth of large-colony PPLO; this was confirmed by the observations that large-colony PPLO grew to a larger size on Klieneberger-Nobel medium and that the colonies were of a more typical "fried egg" appearance on this medium. Conversely, however, T-strain colonies grew in 2 days on the enriched Difco medium but required 4 to 5 days to grow on the Klieneberger-Nobel medium. Nevertheless, it was very evident that either medium could be used to study either type of organism.

TABLE III

COMPARISON OF ENRICHED DIFCO AND KLIENEBERGER NOBEL MEDIA FOR THE ISOLATION OF GENITAL PPLO

\begin{tabular}{|c|c|c|c|}
\hline PPLO & $\cdots$ & T-strains & $\begin{array}{l}\text { Large-Colony } \\
\text { Strains }\end{array}$ \\
\hline \multicolumn{2}{|c|}{ Total Number of Isolations } & 107 & 57 \\
\hline \multirow{2}{*}{$\begin{array}{l}\text { No. } \\
\text { lsolated }\end{array}$} & On Difco Medium & 106 & 53 \\
\hline & $\begin{array}{c}\text { On Klieneberger- } \\
\text { Nobel Medium }\end{array}$ & 103 & 57 \\
\hline
\end{tabular}

Four methods of incubation were studied during the course of this investigation. Whereas Fortner's anaerobic method and incubation in 10 per cent. $\mathrm{CO}_{2}$ gave similar results, aerobic incubation yielded lower isolation rates and the colonies of both types of PPLO grew more slowly. Later in the study 20 per cent. $\mathrm{CO}_{2}$ with nitrogen was employed and this increased the size of the T-strain colonies and caused them to demonstrate surface growth. Thus, under this latter atmospheric condition, T-strain colonies more closely simulated the large-colony types, from which they could still be differentiated readily by their smaller size and more greenish-blue colour with Dienes' stain.

\section{Discussion}

There is general agreement that non-gonococcal urethritis is most effectively treated by broadspectrum antibiotics such as tetracycline. In a basically abacterial condition such as non-gonococcal urethritis, this therapeutic observation would well conform to the hypothesis that PPLO are aetio- 
logical agents and the finding that 84 per cent. of patients with non-gonococcal urethritis had PPLO in their urethral exudate would support such a contention. Moreover, the results of the present study would suggest that T-strain PPLO were more likely to be the responsible organisms than the largecolony strains. This view, however, affords no explanation for the presence of PPLO in up to 55 per cent. of individuals without urethritis, and it would, therefore, seem that other factors must be invoked to explain why PPLO might be pathogenic in one individual and saprophytic in another.

There is no doubt that the result of any cultural study of PPLO from the male urethra depends on the methods employed in the investigation. On the basis of the present work, a deep urethral scraping cultured on Difco PPLO medium, enriched in the manner described, incubated by Fortner's method, or in 10 per cent. $\mathrm{CO}_{2}$ or 20 per cent. $\mathrm{CO}_{2}$ with nitrogen and examined by Dienes's technique, would provide a reliable and practical procedure for the study of both types of PPLO. Aerobic incubation is inadequate and Dienes's method of staining is essential; moreover, a very close association between the clinical handling of patients and the laboratory is also almost essential.

\section{Summary}

PPLO were demonstrable in the urethral exudate of 84 per cent. of patients with non-gonococcal urethritis, and in 79 of 100 such cases T-strain PPLO were isolated. These observations have been compared with the findings in two groups of "control" males without urethritis. Their significance is discussed.

The investigation was supported by the Canadian Arthritis and Rheumatism Society and Federal Health Grant No. 609-7-40. The authors gratefully acknowledge the co-operation of the staffs of the Vancouver Venereal Diseases Control Clinic, Okalla Prison Farm, and 4,000 Medical Unit Auxillary R.C.A.F. The assistance of George Rasmussen and Peter Wall is also acknowledged. Drs. W. F. Bie, K. G. Nickerson, F. W. Tysoe, and H. G. Wadman kindly allowed us to study their patients.

\section{REFERENCES}

Ford, D. K. (1962). J. Bact., 84, 1028.

and MacDonald, J. (1963). Ibid., 85, In the press.

-, Rasmussen, G., and Minken, J. (1962). Brit. J. vener. Dis., 38, 22.

Klieneberger-Nobel, E. (1959). Brit. med. J., 1, 19.

(1961), "Pleuropneumonia-like organisms (PPLO) Mycoplasmataceae". Academic Press, London.

Shepard, M. C. (1956). J. Bact., 71, 362.

Souches génitales du microbe de la péripneumonie des bovidés (PPLO) chez l'homme

\section{RÉSUMÉ}

On trouva les PPLO dans l'exsudat urétral de $84 \%$ des malades atteints d'urétrite non-gonococcique, et dans 79 cas sur 100 on put isoler les PPLO de souche T.

On compare ces résultats avec ceux de deux séries de témoins sans urétrite, et on en discute l'importance. 